\title{
IDLENESS
}

$x$ 


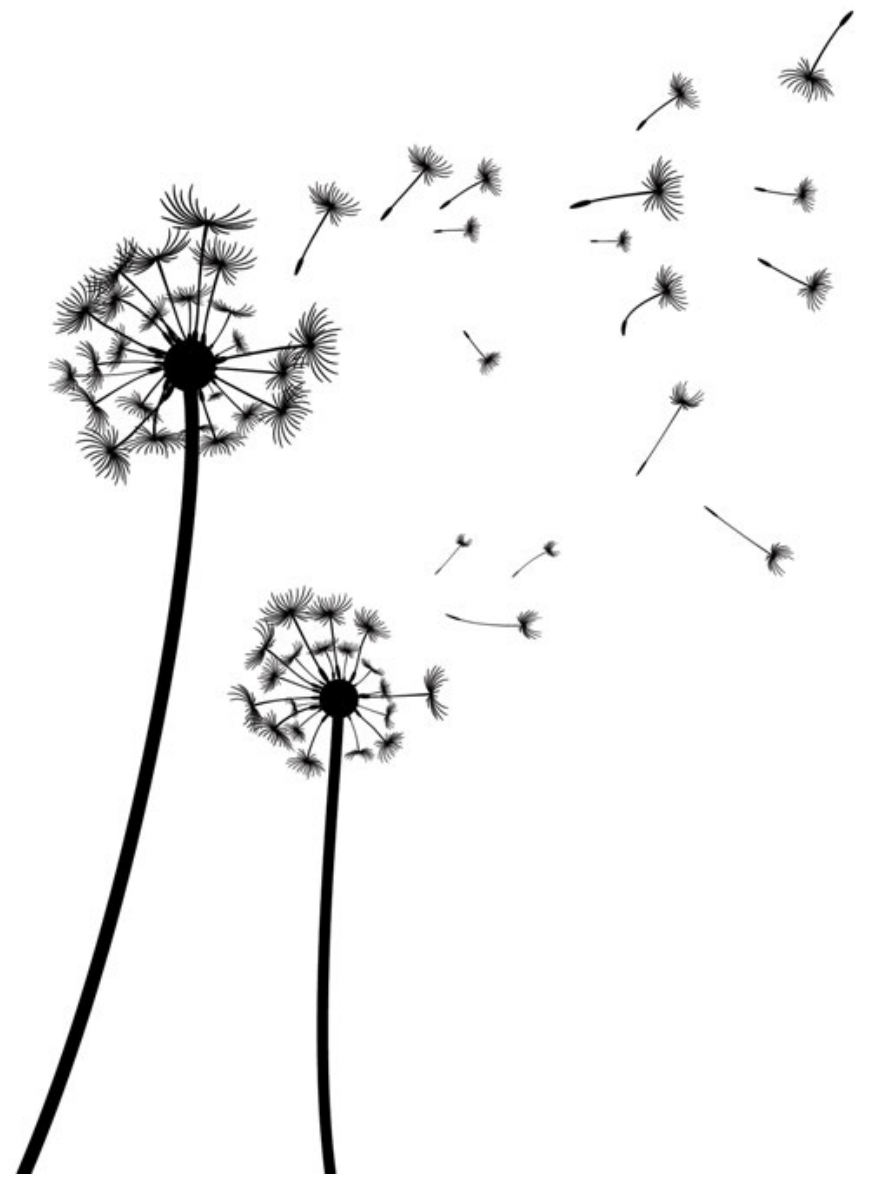




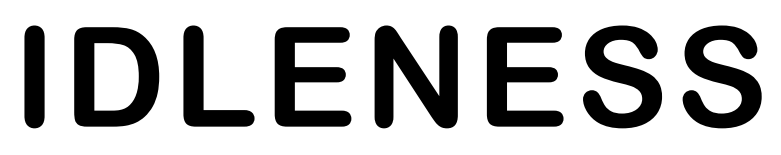

A PHILOSOPHICAL ESSAY

\section{BRIAN O'CONNOR}

PRINCETON UNIVERSITY PRESS

PRINCETON AND OXFORD 
Copyright (C) 2018 by Princeton University Press

Published by Princeton University Press,

41 William Street, Princeton, New Jersey 08540

In the United Kingdom: Princeton University Press, 6 Oxford Street, Woodstock, Oxfordshire OX20 1TR press.princeton.edu

Jacket image courtesy of Shutterstock

All Rights Reserved

ISBN 978-0-691-16752-7

Library of Congress Control Number: 2018937064

British Library Cataloging-in-Publication Data is available

This book has been composed in Garamond Premier Pro and Arial Rounded

Printed on acid-free paper. $\infty$

Printed in the United States of America

13579108642 
For Jane and Anna 
